\title{
PENGARUH COST OF REM TERHADAP REAL EARNINGS MANAGEMENT \\ DENGAN ASET DAN MARKET TO BOOK VALUE SEBAGAI VARIABEL KONTROL
}

\section{Tri Yulaeli}

\section{Dosen Universitas Mathla'ul Anwar Banten}

Cahyadewi27@gmail.com

\begin{abstract}
The purpose of this study is To know how the influence of cost of rem can influence real earnings management with control variable asset and market to book value, the study population is 147 manufactured companies registered in Bursa Efek Indonesia in 2011-2016 and the sample research into 35 companies with research methods.

The type of research used is associative research that is associative technique of associative research using quantitative analysis technique (statistic). To know the amount of influence between variable of writer use data analysis with help SPSS 20.

The result of research proves that there is financial distress no significant to real earnings management or hypothesis $\left(H_{1}\right)$ rejected, institutional ownerships no significant to real earnings management or hypothesis $\left(\mathrm{H}_{2}\right)$ rejected and $\mathrm{H}_{3}$ accepted means family ownerships have a negative significant to real earnings management.
\end{abstract}

Keyword :real earnings management, financial distress, institutional ownership, family ownerships

\section{PENDAHULUAN}

Manajemen laba menyajikan mekanisme sinyal dari manajemen (Sankar \& Subramanyan, 2001; Stocken \& Verrecchia, 2004) dan dapat diperlakukan dan tidak dapat diperlakukan sebagai perilaku oportunistik (Hadani et al., 2011).Peran oportunis yang lebih umum pada perusahaan publik adalah aktivitas berbasis akrual 
dan riil yang merupakan dua peluang alternatif dalam mengelola pendapatan (Dechow et al., 2012; Man \& Wong, 2013). Tindakan manajemen laba ini dapat diklasifikasikan menjadi dua kategori yaitu accruals management dan real activities manipulation (REM).

Perbedaan kepentingan antara pemegang saham dan manajemen dapat menyebabkan keputusan manajemen yang kurang optimal.Teori agensi mengemukakan bahwa mekanisme pemantauan dapat memperbaiki penyelarasan manajemen dan kepentingan pemegang saham dan dapat mengurangi perilaku oportunis yang diakibatkan oleh konflik kepentingan antara pemegang saham dan manajemen (Alves, 2012).Perusahaan yang dimiliki oleh keluarga disebut controlling shareholders atau memiliki saham kurang lebih $20 \%$ dari voting rights dan merupakan pemilik saham tertinggi dibandingkan dengan shareholders yang lain. Perusahaan keluarga sering memunculkan isu mengenai pengungkapan perusahaan terutama tentang kualitas pengungkapan perusahaan. Rendahnya kualitas pengungkapan perusahaan, dalam hal ini manajemen laba dikarenakan tingginya level konsentrasi kepemilikan saham dan kurangnya market monitoring yang menyebabkan tingginya controlling shareholders untuk mengekspropriasi atau mengambil alih minority shareholders (Stockmans et al., 2010).

Swai dan Mbolega (2016) menjelaskan bahwa struktur kepemilikan memiliki implikasi pada manajemen laba berbasis akrual.Selain itu, konsentrasi kepemilikan dan kepemilikan institusional berpengaruh negatif yang signifikan terhadap pengelolaan manajemen laba riil.Sedangkan Liu dan Tsai (2015) menemukan bahwa kepemilikan institusional memainkan peranan penting dalam membatasi tindakan manajemen laba aktivitas riil.

Negar dan Sen (2016) menjelaskan bahwa perusahaan pada tahap awal mengalami distressakan melakukan manajemen laba riil melalui pengurangan pengeluaran untuk penjualan, umum dan biaya administrasi dan terlibat dalam penggolongan klasifikasi untuk meningkatkan profitabilitas dan likuiditas. 
Mohammadi dan Amini (2016) menjelaskan bahwa peningkatan free cash flow sebagai standar dari financial distressakan meningkatkan manajemen laba. Hal ini menunjukkan adanya pengaruh positif dan hubungan yang signifikan antara financial distress dan manajemen laba. Hal ini dapat dijelaskan bahwa free cash flow perusahaan dapat dianggap sebagai faktor motif dari manajemen laba.

Achleitner et al. (2008), Ghabdian et al. (2012) dan Munir et al (2013) menjelaskan bahwa usaha keluarga telah menjadi bagian utama pasar modal. Dengan memiliki saham bersama atau menjadi anggota dewan, anggota keluarga dianggap sebagai pengambilan keputusan utama dalam bisnis keluarga. Disisi lain, laba selalu menjadi indikator kinerja yang berada dalam kendali manajemen dan paling sering dikelola atau dimanipulasi. Perusahaan dengan tingkat kepemilikan manajemen laba yang rendah akan melaporkan kualitas pendapatan yang tinggi meskipun tingkat perlindungan investornya rendah. Namun, ketika sebuah keluarga memiliki saham yang signifikan dalam sebuah perusahaan, aktivitas pengambil alihan berdampak negatif terhadap kualitas pendapatan perusahaan.Dari penjelasan tersebut maka penulis tertarik untuk mengetahui bagaimana "Cost of REM Mempengaruhi Real Earnings Management Dengan Variabel Kontrol Aset dan Market to Book Value"

Berdasarkan uraian diatas maka masalah dalam penelitian ini dirumuskan sebagai berikut:

\section{Financial Distress}

Riset ini bermaksud mengkonfirmasi apakah financial distress yang dialami oleh perusahaan memiliki hubungan positif dan signifikan terhadap real earnings management.Penelitian ini mengkonfirmasi real earnings management diukur dengan aktivitas riil, yaitu biaya produksi, arus kas operasi dan discretionary expense.

\section{Kepemilikan Institusional}


Rumusan masalah ini dirancang untuk mengetahui apakah kepemilikan institusional dapat meningkatkan tindakan real earnings management yang dilakukan oleh manajer.Penelitian ini mengkonfirmasi kepemilikan institusional diukur dengan presentasi saham yang dimiliki oleh institusi.

\section{Kepemilikan Keluarga}

Rumusan masalah ini dirancang untuk mengetahui apakah kepemilikan keluarga dapat menurunkan tindakan real earnings management yang dilakukan oleh manajer.Penelitian ini mengkonfirmasi kepemilikan keluarga diukur dengan presentasi saham yang dimiliki oleh keluarga.

Berdasarkan perumusan masalah diatas, maka tujuan dari penelitian ini adalah untuk menguji pengaruh cost of rem terhadap real earnings managementdengan menjadikan aset dan market to book value sebagai variabel kontrol bagi cost of rem.

Penelitian ini diharapkan memberikan kontribusi teori tentang financial distress, kepemilikan institusional dan kepemilikan keluarga yang dapat mempengaruhi tinggi rendahnya tindakan real earnings management.Serta Kontribusi Praktekbagaimana caramengurangi tindakan real earnings management sehingga tidak merugikan investor yang akan menanamkan investasinya diperusahaan, serta Kontribusi Kebijakan akan memberikan gambaran mengenai hal-hal yang berdampak apabila dilakukan tindakan real earnings management sehingga berpengaruh terhadap kebijakan yang dikeluarkan manajemen ataupun pemerintah dalam rangka meningkatkan perekonomian bangsa

\section{TINJAUAN PUSTAKA DAN HIPOTESIS}

\section{LANDASAN TEORI}

Teori keagenan adalah hubungan antara dua pihak yang terlibat dalam suatu kontrak yang terdiri dari agen sebagai pihak yang diberikan tanggung jawab untuk 
suatu tugas dan prinsipal sebagai pihak pemberi tugas. Kondisi ini menjelaskan konsekuensi bahwa kedua belah pihak, agen maupun prinsipal, akan berusaha untuk memaksimalkan kegunaannya masing-masing (Jensen dan Meckling, 1976). Secara bertahap, teori agensi diperluas ke area manajer untuk menentukan kerjasama antara berbagai pihak dengan berbagai tujuan dalam perusahaan serta berbagai pencapaian tujuan (Eisenhardt, 1989).

Brigham dan Houston (2006) menjelaskan bahwa teori sinyal adalah suatu tindakan yang diambil oleh perusahaan untuk memberi petunjuk bagi investor mengenai bagaimana manajemen melihat prospek perusahaan.Teori sinyal secara general membahas mengenai sinyal-sinyal keberhasilan perusahaan yang dicapai manajemen juga kegagalan perusahaan yang disampaikan kepada para pemilik perusahaan dalam bentuk laporan keuangan dan dianggap sebagai sinyal dari manajemen telah berbuat sesuai dengan kontrak yang disepakati.

\section{Manajemen LabaRiil}

Roychowdhury (2006) menyatakan bahwa manajemen laba riil dapat dideteksi melalui 3 hal yaitu arus kas operasi, biaya produksi dan biaya diskresioner perusahaan.Cara yang digunakan oleh manajer dalam praktik manipulasi arus kas operasi tersebut diantaranya adalah dengan melakukan manipulasi penjualan. Manajer menggunakan kebijakan diskon besar-besaran sebagai salah satu cara untuk meningkatkan penjualan dan berdampak pada arus kas operasi yang masuk ke dalam perusahaan. Dengan demikian, volume penjualan perusahaan pada tahun tersebut akan naik. Cara yang lainnya adalah dengan pemberian kredit ringan yang akan meningkatkan penjualan namun memperkecil arus kas operasi yang masuk ke dalam perusahaan atau penundaan pembayaran bahan baku kepada supplier sehingga volume arus kas di dalam perusahaan menjadi tinggi. Pihak manajemen memanipulasi biaya produksi dengan cara membesarkan volume produksi di tahun berjalan.

\section{Financial Distress}


Financial distress mengacu kepada ketidakmampuan perusahaan untuk membayar hutang dan kewajiban dilihat.Ketidakmampuan tersebut berasal dari arus kas dan profitabilitas yang buruk.Distress menimbulkan tantangan baru sebelum manajer perusahaan mengambil tindakan ekonomi riil yang mengarah pada perbaikan kinerja perusahaan yang telah berjalan lama. Namun, karena dalam keadaan distress manajer takut akan melanggar perjanjian hutang, kehilangan pekerjaannya dan keputusan ekonomi yang masuk diakal dapat memberikan imbalan jangka panjang bagi manajer sehingga insentif jangka pendek lebih besar dari insentif jangka panjang dan manajer dapat menikmati taktik yang menunjukkan peningkatan kinerja jangka panjang dalam waktu singkat (Negar dan Sen, 2016).

\section{Kepemilikan Institusional}

Jensen dan Meckling (1976) menjelaskan bahwa kepemilikan institusional memiliki peran yang sangat penting dalam meminimalkan konflik keagenan yang terjadi antara manajer dan pemegang saham. Kepemilikan institusional adalah kepemilikan saham perusahaan oleh institusi keuangan seperti perusahaan asuransi, bank, dana pensiun dan investment banking. Bushee (1998) menganggap bahwa investor institusi akan mendorong manajer untuk lebih mementingkan kepentingan jangka pendek dan mengorbankan kepentingan jangka panjang perusahaan yang bertujuan untuk memenuhi target pendapatan untuk kepentingan pribadi.

\section{Kepemilikan Keluarga}

Kepemilikan keluarga merupakan kepemilikan saham individu maupun perusahaan yang bukan publik (Faccio dan Lang, 2001).Kepemilikan keluarga merupakan kepemilikan individu dan kepemilikan perusahaan tertutup (diatas 5\%) yang bukan perusahaan publik, negara ataupun institusi keuangan (La Porta et al., 2000:22).Perusahaan dengan kepemilikan keluarga merupakan mayoritas jenis perusahaan di Indonesia. 


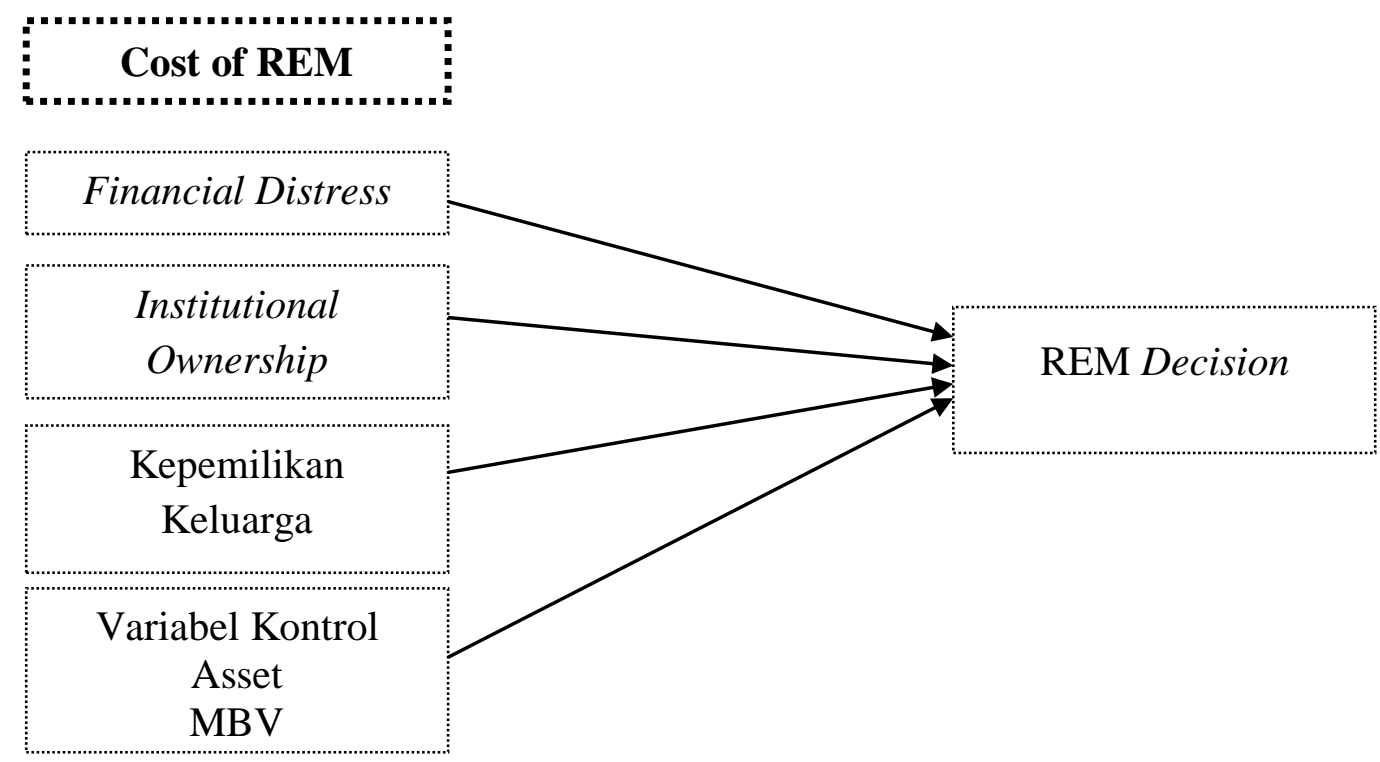

Gambar 1

\section{Rerangka Teoritis}

\section{PENGEMBANGAN HIPOTESIS}

\section{Financial Distress dan Earnings Management}

Financial distress merupakan suatu kondisi perusahaan yang sedang mengalami penyimpangan dan tekanan keuangan yang secara bertahap akan mengarah kepada kebangkrutan (Platt dan Platt, 2006). Perusahaan pada tahap awal mengalami kesulitan melakukan manajemen laba riil melalui pengurangan pengeluaran dari penjualan, biaya umum dan administrasi serta terlibat dalam penggolongan klasifikasi untuk meningkatkan profitabilitas dan likuiditas.Negar dan Sen (2016) dalam penelitiannya yang bertujuan meneliti financial distress dan tingkat distress memiliki peran dalam keputusan manajer dalam melakukan manajemen laba.Hassanpour dan Ardakani (2017) dalam penelitiannya yang bertujuan yang meneliti pengaruh gangguan keuangan sebelum kebangkrutan terhadap manajemen laba Hasil dari penelitian ini adalah menunjukkan hubungan positif yang signifikan 
antara financial distress sebelum kebangkrutan dengan manajemen laba riil dan manajemen laba berbasis akrual.

\section{H1: Terdapat pengaruh positif antarafinancial distress terhadap real earnings management}

\section{Kepemilikan Institusional dan Earnings Management}

Jensen dan Meckling (1976) menjelaskan bahwa kepemilikan institusional memiliki peran yang sangat penting dalam meminimalkan konflik keagenan yang terjadi antara manajer dan pemegang saham. Kepemilikan institusional adalah kepemilikan saham perusahaan oleh institusi keuangan seperti perusahaan asuransi, bank, dana pensiun dan investment banking. Kepemilikan insider yang lebih substansial dapat secara efektif mengatur manajer dan melarang mereka memanipulasi laba riil dan menyebabkan kerugian nilai perusahaan.Kepemilikan institusional dari perusahaan memiliki peranan penting dalam membatasi praktik manajemen laba riil.Selain itu, kepemilikan manajerial tidak mempengaruhi pemilik saham dalam melakukan tindakan manajemen laba riil.Hsu dan Wen (2015) yang meneliti pengaruh struktur kepemilikan dan karakteristik dewan terhadap manajemen laba berbasis akrual dan manajemen laba riil menemukan bahwa kepemilikan institusional dengan proporsi saham yang tinggi atau konsentrasi kepemilikan saham yang besar memberikan manajer insentif untuk memanipulasi akrual diskresioner untuk keuntungan jangka pendek.Liu dan Tsai (2015) yang meneliti pengaruh karakteristik dewan direksi dan struktur kepemilikan terhadap manajemen laba riil menunjukkan bahwa kualitas direksi lebih cenderung mempengaruhi manajemen laba riil dan mengindikasikan bahwa hasil ini berhasil menggambarkan efektifitas dari karakteristik dewan direksi pada perusahaan.

H2: Terdapat pengaruh positif antara kepemilikan institusional dan real earnings management

\section{Kepemilikan Keluarga dan Earnings Management}


Kepemilikan keluarga merupakan kepemilikan saham individu maupun perusahaan yang bukan publik (Faccio dan Lang, 2002).Kepemilikan keluarga merupakan kepemilikan individu dan kepemilikan perusahaan tertutup (diatas 5\%) yang bukan perusahaan publik, negara ataupun institusi keuangan (La Porta et al., 1998:22). Rendahnya kualitas pengungkapan perusahaan, dalam hal ini manajemen laba dikarenakan tingginya level konsentrasi kepemilikan saham dan kurangnya market monitoring yang menyebabkan tingginya controlling shareholders untuk mengekspropriasi atau mengambil alih minority shareholders (Stockmans et al., 2010). Achleitner et al. (2008), Ghabdian et al. (2012) dan Munir et al (2013) menjelaskan bahwa usaha keluarga telah menjadi bagian utama pasar modal. Dengan memiliki saham bersama atau menjadi anggota dewan, anggota keluarga dianggap sebagai pengambilan keputusan utama dalam bisnis keluarga. Disisi lain, laba selalu menjadi indikator kinerja yang berada dalam kendali manajemen dan paling sering dikelola atau dimanipulasi. Perusahaan dengan tingkat kepemilikan manajemen laba yang rendah akan melaporkan kualitas pendapatan yang tinggi meskipun tingkat perlindungan investornya rendah. Namun, ketika sebuah keluarga memiliki saham yang signifikan dalam sebuah perusahaan, aktivitas pengambil alihan berdampak negatif terhadap kualitas pendapatan perusahaan.

\section{H3: Terdapat pengaruh negatif antara kepemilikan keluargadan real earnings management.}

\section{METODELOGI PENELITIAN}

\section{Variabel Penelitian dan Pengukuran}

Variabel dependen yang digunakan adalah earnings management dari aktivitas riil.Semua variabel dibagi dengan total aset untuk mengurangi heteroskedastisitas. Rumus yang digunakan adalah sebagai berikut: 


$$
\frac{P R O D_{t}}{A_{t-1}}=\alpha_{0}+\alpha_{1}\left(\frac{1}{A_{t-1}}\right)+\alpha_{2}\left(\frac{S_{t}}{A_{t-1}}\right)+\alpha_{3}\left(\frac{\Delta S_{t}}{A_{t-1}}\right)+\alpha_{4}\left(\frac{\Delta S_{t-1}}{A_{t-1}}\right)+\varepsilon_{t}
$$

Dimana:

PRODt $=$ The sum of COGS in event year $t$ and the change in inventory

At-1 = Lagged total assets

St $\quad=$ Net revenues in the current period

$\Delta \mathrm{St}=\Delta$ Penjualan Bersih (Change in net revenues)

$\Delta \mathrm{St}-1=$ Change in net revenues in the prior period

et $\quad=$ Unstandardized residual

Level normal biaya diskresioner diestimasi berikut:

$$
\frac{D I S X_{t}}{A_{t-1}}=\alpha_{0}+\alpha_{1}\left(\frac{1}{A_{t-1}}\right)+\alpha_{2}\left(\frac{S_{t}}{A_{t-1}}\right)+\varepsilon_{t}
$$

Dimana:

DISXt $=$ Discretionary expenses termasuk jumlah SG\&A dan R\&D.

Mengacu pada Roychowdhury (2006) bahwa bila R\&D tak ada dan G\&A tersedia, maka biaya $\mathrm{R} \& \mathrm{D}=0$.

PengukuranabnormalCFOsebagai proxi untukMRPengukuran initelah dikritikkarenamanipulasiarus kasdan metodeMR yang lain memiliki efekmeyakinkan padaCFOdan karena itusulit untuk menghargaiTingkat normalCFOdihasilkan melaluipersamaan berikut:

$$
\frac{C F O_{t}}{A_{t-1}}=\alpha_{0}+\alpha_{1}\left(\frac{1}{A_{t-1}}\right)+\alpha_{2}\left(\frac{S_{t}}{A_{t-1}}\right)+\alpha_{3}\left(\frac{\Delta S}{A_{t-1}}\right)+\varepsilon
$$

Dimana:

$\mathrm{CFO} \mathrm{t}=$ Funds from operations for current period 


\section{Variabel Independen}

\section{Financial Distress}

Financial distress dalam penelitian ini menggunakan model Z-Score Altman (1968, 2000). Rumusnya adalah sebagai berikut:

$$
\text { Z-Score }=6,56 \mathrm{~T} 1+3,26 \mathrm{~T} 2+6,72 \mathrm{~T} 3+1,05 \mathrm{~T} 4
$$

Dimana:

$\mathrm{Z} \quad=$ Z-Skor Indeks

T1 = Working Capital/Total Assets

T2 = Retained Earnings/Total Assets

$\mathrm{T} 3=$ Earnings Before Interest and Tax/Total Asset

T4 = Book Value of Equity/Book Value of Liabilities

Berdasarkan persamaan Z-Skor maka diperoleh nilai Z dengan cut off value sebagai berikut:

1. Jika nilai $Z>2,60$ maka dapat dikategorikan dalam kondisi sehat (save zone)

2. Jika nilai $1,1<\mathrm{Z} \leq 2,60$ maka dikategorikan perusahaan dalam kondisi yang terdapat sinyal atas potensi kebangkrutan (grey area)

3. Jika nilai $\mathrm{Z} \leq 1,1$ maka perusahaan dikategorikan sedang dalam kondisi kesulitan keuangan dan memiliki potensi kebangkrutan yang tinggi.

\section{Kepemilikan Institusional}

Variabel kepemilikan institusional menggunakan model Zang (2012) yaitu jumlah presentase kepemilikan institusional. Yang rumusnya adalah sebagai berikut:

$$
\mathrm{KI}=\frac{\text { Jumlah Saham Kepemilikan Institusional }}{\text { Total Jumlah Saham }}
$$

\section{Kepemilikan Keluarga}


Variabel kepemilikan keluarga menggunakan rumus dari Munir et al (2013). Yang rumusnya adalah sebagai berikut:

$$
\mathrm{KK}=\frac{\text { Jumlah Saham Kepemilikan Keluarga }}{\text { Total Jumlah Saham }}
$$

\section{Variabel Kontrol}

Aset dalam penelitian ini diukur menggunakan total aset perusahaan manufaktur pada periode penelitian.Market to book value dalam penelitian ini menggunakan rumus nilai pasar saham bursa dibagi dengan nilai saham yang dibukukan oleh perusahaan manufaktur. Rumusnya adalah sebagai berikut:

$$
\text { Market to book value }=\frac{\text { Harga Pasar Saham }}{\text { Nilai Buku Saham }}
$$

Dimana:

Nilai Buku Saham = total ekuitas/jumlah saham yang beredar

\section{Objek Penelitian}

Objek penelitian ini adalah perusahaan manufaktur yang terdaftar di Bursa Efek Indonesia periode 2011-2016, dimana untuk pengambilan data-data seperti laporan keuangan melalui situs www.idx.co.id. Populasi penelitian adalah 147 perusahaan manufaktur yang terdaftar di Bursa Efek Indonesia, sedangkan sample penelitian adalah 35 perusahaan.Teknik pengambilan sampel yang digunakan dalam penelitian ini adalah adalah purposive sampling.

\section{Pengumpulan Data}

Pengumpulan data yang dilakukan penulis dengan metode observasi dan teknik pengumpulan data arsip dimana data yang diolah adalah data sekunder yaitu data kuantitatif yang disediakan oleh organisasi (unit bisnis) sehingga peneliti tinggal menggunakan dan mengolah data 


\section{HASIL DAN PEMBAHASAN}

Penelitian ini dilakukan pada perusahaan manufaktur yang terdaftar di Bursa Efek Indonesia periode 2011 sampai dengan 2016.Berdasarkan karakteristik sampel yang telah ditetapkan, maka sampel yang digunakan dalam penelitian ini sebanyak 35 perusahaan.berikut disajikan data statistic deskriptif dari sampel yang diteliti:

\section{Tabel 1}

\section{Karakteristik Sampel Penelitian}

\begin{tabular}{|l|c|}
\hline \multicolumn{1}{|c|}{ Keterangan } & Jumlah \\
\hline $\begin{array}{l}\text { Perusahaan manufaktur yang telah terdaftar } \\
\text { di Bursa Efek Indonesia (BEI) untuk } \\
\text { periode 2011-2016 }\end{array}$ & 147 \\
\hline $\begin{array}{l}\text { Perusahaan yang tidak rutin mengeluarkan } \\
\text { laporan keuangan untuk periode 2011-2016 }\end{array}$ & $(31)$ \\
\hline $\begin{array}{l}\text { Perusahaan yang mengalami kerugian untuk } \\
\text { periode 2011-2016 }\end{array}$ & $(17)$ \\
\hline $\begin{array}{l}\text { Perusahaan yang tidak memiliki data } \\
\text { lengkap pada laporan keuangan untuk } \\
\text { periode 2011-2016 }\end{array}$ & $(9)$ \\
\hline Perusahaan yang terkena uji outlier & 26 \\
\hline $\begin{array}{l}\text { Perusahaan manufaktur di Bursa Efek } \\
\text { Indonesia yang menjadi sampel penelitian }\end{array}$ & 6 \\
\hline Periode pengamatan 2011-2016 & 156 \\
\hline $\begin{array}{l}\text { Jumlah data yang digunakan menjadi } \\
\text { sampel }\end{array}$ & \\
\hline Sumber: & \\
\hline
\end{tabular}

Sumber: $\underline{\text { ww.idx.co.id }}$

Berdasarkan tabel diatas, perusahaan yang dijadikan sampel penelitian adalah sebanyak 26 perusahaan manufaktur selama tahun 2011-2016.Sehingga, total sampel yang digunakan adalah sebanyak 156 perusahaan. Berikut disajikan data statistik deskriptif dari sampel penelitian:

\section{Tabel 2}

\section{Statistik Deskriptif}




\begin{tabular}{|c|c|c|c|c|c|}
\hline Variabel & $\mathbf{N}$ & Min & Max & Mean & Std.Deviasi \\
\hline REM & 156 & -0.33 & 0.22 & -0.0048 & 0.09378 \\
\hline Financial Distress & 156 & -24.05 & 16.50 & 5.0399 & 5.01057 \\
\hline Kepemilikan Institusional & 156 & 0.06 & 0.96 & 0.6179 & 0.18939 \\
\hline Kepemilikan Keluarga & 156 & 0.13 & 0.88 & 0.5075 & 0.19723 \\
\hline Aset & 156 & 11.07 & 13.85 & 12.3720 & 0.63824 \\
\hline Market to Book Value & 156 & -0.01 & 8.57 & 1.5372 & 1.68017 \\
\hline
\end{tabular}

Sumber: data diolah dengan SPSS 20

Berdasarkan data statistik, dapat dilihat bahwa real earnings management memiliki nilai terendah sebesar -0.33 dan tertinggi sebesar 0.22 dengan nilai rata-rata sebesar -0.0048 dan nilai standar deviasi sebesar 0.09378. Financial distress nilai terendah sebesar -24.05 dan nilai tertinggi sebesar 16.50.Dengan nilai rata-rata sebesar 5.0399 dan nilai standar deviasi sebesar 5.01057.Kepemilikan institusional nilai terendah sebesar 0.06 dan nilai tertinggi sebesar 0.96.Dengan nilai rata-rata sebesar 0.6179 dan nilai standar deviasi sebesar 0.18939.Kepemilikan keluarga nilai terendah sebesar 0.13 dan nilai tertinggi sebesar 0.88.Dengan nilai rata-rata sebesar 0.5075 dan nilai standar deviasi sebesar 0.19723. Aset nilai terendah sebesar 11.07 dan nilai tertinggi sebesar 13.85.Dengan nilai rata-rata sebesar 12.3720 dan nilai standar deviasi sebesar 0.63824.Market to book value nilai terendah sebesar -0.01 dan nilai tertinggi sebesar 8.57.Dengan nilai rata-rata sebesar 1.5372 dan nilai standar deviasi sebesar 1.68017 .

\section{Tabel 3}

\section{Frekuensi Financial Distress}

\begin{tabular}{|c|c|c|}
\hline Keterangan & Frekuensi & Presentase \\
\hline Save Zone & 125 & $80.1 \%$ \\
\hline Grey Area & 21 & $13.5 \%$ \\
\hline Distress & 10 & $6.4 \%$ \\
\hline Total & $\mathbf{1 5 6}$ & $\mathbf{1 0 0}$ \\
\hline
\end{tabular}

Sumber: data diolah dengan SPSS 20

Berdasarkan tabel diatas, dapat dilihat bahwa terdapat 125 perusahaan atau $80.1 \%$ perusahaan yang berada di save zone dan 21 perusahaan atau $13.5 \%$ dari total 
perusahaan berada pada grey area. Sedangkan perusahaan yang mengalami distress sebanyak10 perusahaan atau $6.4 \%$ dari total perusahaan.

\section{Tabel 4}

\section{Uji Asumsi Klasik}

\begin{tabular}{|c|c|c|c|c|}
\hline Uji & Variabel & \multicolumn{2}{|c|}{ Nilai Sig. } & Hasil \\
\hline Normalitas & & \multicolumn{2}{|c|}{0.633} & $\begin{array}{l}\text { Data berdistribusi normal nilai } \\
\text { signifikan lebih besar dari } 0.05\end{array}$ \\
\hline \multirow{6}{*}{ Multikolinearitas } & Variabel & Tolerance & VIF & \multirow{6}{*}{$\begin{array}{l}\text { Tidak terjadi multikolinearitas } \\
\text { Nilai tolerance lebih besar dari } 0.1 \\
\text { dan nilai VIF lebih kecil dari } 10\end{array}$} \\
\hline & FD & 0.902 & 1.109 & \\
\hline & KI & 0.776 & 1.289 & \\
\hline & KK & 0.808 & 1.238 & \\
\hline & Aset & 0.813 & 1.231 & \\
\hline & MBV & 0.833 & 1.201 & \\
\hline \multirow{6}{*}{ Heteroskedastisitas } & Variabel & \multicolumn{2}{|c|}{ Nilai Sig. } & \multirow{6}{*}{$\begin{array}{l}\text { Tidak terjadi heteroskedastisitas nilai } \\
\text { signifikan lebih besar dari } 0.05\end{array}$} \\
\hline & FD & 0.4 & & \\
\hline & $\mathrm{KI}$ & 0.12 & & \\
\hline & KK & 0.4 & & \\
\hline & Aset & 0.8 & & \\
\hline & MBV & 0.79 & & \\
\hline \multirow[b]{2}{*}{ Autokorelasi } & & Nilai & & \multirow{2}{*}{$\begin{array}{c}\text { Tidak terjadi autokorelasi } \\
\text { Du : } 1.665 \text { DL }: 1.802 \text { 4-DU } 2.335 \\
\text { dan 4-DL : } 2.198 \text { nilai DW berada } \\
\text { diantara DL dan 4-DL }\end{array}$} \\
\hline & & \multicolumn{2}{|c|}{1.870} & \\
\hline
\end{tabular}

Sumber: data diolah dengan SPSS 20

Berdasarkan tabel diatas, hasil dari uji asumsi klasik yang dilakukan untuk menguji apakah data-data yang dijadikan sampel penelitian lolos dari uji asumsi klasik. Berikut hasil uji hipotesis dari penelitian:

\section{Tabel 5}

\section{Hasil Uji}

\begin{tabular}{|c|c|c|c|}
\hline Variabel & $\boldsymbol{\beta}$ & Sig. & Keputusan \\
\hline Constant & 0.357 & & \\
\hline
\end{tabular}




\begin{tabular}{|c|c|c|c|}
\hline Financial Distress & 0.114 & 0.160 & Ha ditolak \\
\hline Kepemilikan Institusional & 0.127 & 0.148 & Ha ditolak \\
\hline Kepemilikan Keluarga & -0.186 & 0.031 & Ha diterima \\
\hline Aset & -0.197 & 0.022 & \\
\hline Market to Book Value & -0.090 & 0.287 & \\
\hline Adjusted R ${ }^{2}$ & 0.087 & \\
\hline Uji F & 3.967 & \\
\hline F Sig. & 0.002 & \\
\hline
\end{tabular}

Sumber: data diolah dengan SPSS 20

Berdasarkan tabel diatas, nilai adjusted $\mathrm{R}^{2}$ adalah sebesar 0.087 , yang artinya variabel independen hanya mampu mempengaruhi variabel real earnings management sebesar 8,7\% dan sisanya sebesar $91.3 \%$ dipengaruhi oleh variabel lain yang tidak diteliti dalam penelitian ini. Besarnya pengaruh sebesar $8.7 \%$ merupakan pengaruh yang sangat kecil. Nilai signifikan f sebesar 0.002 lebih besar dari 0.05 menunjukkan bahwa secara bersama-sama variabel financial distress, kepemilikan institusional, kepemilikan keluarga, aset dan market to book value berpengaruh terhadap real earnings management.

Pada tabel diatas dapat dilihat bahwa variabel financial distress dan kepemilikan institusional memiliki nilai signifikan lebih besar dari 0.05.Hasil ini menjelaskan bahwa financial distress dan kepemilikan institusional tidak signifikan terhadap real earnings management.Nilai koefisien regresi dari financial distress adalah sebesar 0.114 yang menunjukkan adanya hubungan searah antara financial distress dan real earnings management.Kepemilikan institusional juga menunjukkan hubungan yang searah dengan real earnings management dengan nilai koefisien regresi sebesar 0.148.Kepemilikan keluarga memiliki nilai signifikan lebih kecil dari 0.05.Hasil ini menjelaskan bahwa kepemilikan keluarga berpengaruh terhadap real earnings management, dengan koefisien regresi sebesar -0.186 yang artinya memiliki hubungan tidak searah dengan real earnings management.Variabel kontrol aset memiliki nilai signifikan lebih kecil dari 0.05 dan menunjukkan hubungan tidak searah dengan real earnings management.Sedangkan, variabel kontrol market to book ratio memiliki nilai signifikan tidak searah dengan real earnings management. 


\section{SIMPULAN DAN KETERBATASAN}

Berdasarkan hasil penelitian, financial distress berpengaruh positif dan tidak signfikan terhadap real earnings management.Hasil penelitian ini tidak sejalan dengan penelitian yang dilakukan oleh Hassanpour dan Ardakani (2017); Negar dan Sen (2016) yang menemukan bahwa financial distress berpengaruh positif terhadap real earnings management. Hasil penelitian ini menunjukkan bahwa arah positif dari financial distress menjelaskan bahwa semakin tingginya kebangkrutan yang dialami oleh perusahaan akan meningkatkan tindakan real earnings management yang dilakukan oleh manajemen untuk mempengaruhi atau meyakinkan investor bahwa perusahaan dalam keadaan aman dan investor tidak akan mengalami kerugian dalam menanamkan investasinya. Namun, hasil penelitian ini tidak signifikan sehingga menjelaskan bahwa meningkatnya financial distress sebuah perusahaan tidak akan mempengaruhi tindakan real earnings management yang akan dilakukan oleh manajemen perusahaan. Manajemen melakukan tindakan tersebut untuk menarik perhatian investor dalam menanamkan investasinya di perusahaan, hal ini dapat terjadi pada semua perusahaan baik perusahaan yang sehat maupun perusahaan yang sedang mengalami kebangkrutan.Selain bertujuan untuk menarik investor, hal ini juga dilakukan untuk mempertahankan reputasi dan citra perusahaan di mata investor dan masyarakat.

Kepemilikan institusional berpengaruh positif dan tidak signifikan terhadap real earnings management.Hasil penelitian ini tidak sejalan dengan penelitian yang dilakukan oleh Hsu dan Wen (2015); Liu dan Tsai (2015) yang menemukan bahwa kepemilikan institusional berpengaruh positif terhadap real earnings management.Arah positif dari hasil penelitian ini menunjukkan bahwa kepemilikan institusional dapat meningkatkan tindakan real earnings management yang dilakukan oleh manajemen. Institusi yang menanamkan saham di perusahaan akan memberikan insentif kepada manajemen untuk memanipulasi laba sebagai bagian dari kepentingan investor. Namun, hasil penelitian ini tidak signifikan sehingga menjelaskan bahwa besar kecilnya kepemilikan institusional dalam perusahaan tidak akan mempengaruhi 
tindakan real earnings management yang akan dilakukan oleh manajer. Manajer tetap akan melakukan tindakan tersebut dengan tujuan untuk menarik investor dan meningkatkan insentif yang akan diterimanya. Semakin investor tertarik maka semakin besar insentif yang akan diterima oleh manajer.

Kepemilikan keluarga berpengaruh negatif terhadap real earnings management, hasil penelitian ini sejalan dengan penelitian yang dilakukan oleh Achleitner et al. (2008), Ghabdian et al. (2012) dan Munir et al (2013) yang menemukan bahwa kepemilikan keluarga berpengaruh negatif terhadap real earnings management. Arah negatif menunjukkan semakin tinggi saham perusahaan dimiliki keluarga maka semakin berkurang manajer melakukan tindakan real earnings management.Dengan memiliki saham bersama atau menjadi anggota dewan, anggota keluarga dianggap sebagai pengambilan keputusan utama dalam bisnis keluarga. Disisi lain, laba selalu menjadi indikator kinerja yang berada dalam kendali manajemen dan paling sering dikelola atau dimanipulasi. Perusahaan dengan tingkat kepemilikan manajemen laba yang rendah akan melaporkan kualitas pendapatan yang tinggi meskipun tingkat perlindungan investornya rendah. Namun, ketika sebuah keluarga memiliki saham yang signifikan dalam sebuah perusahaan, aktivitas pengambil alihan berdampak negatif terhadap kualitas pendapatan perusahaan.

Variabel kontrol aset berpengaruh negatif dan signifikan terhadap real earnings management. Hasil ini menunjukkan bahwa semakin tinggi aset yang dimiliki oleh perusahaan akan mengurangi tindakan manajer dalam melakukan manipulasi laba. Semakin besar aset yang dimiliki oleh perusahaan dapat dijadikan jaminan bahwa perusahaan tidak akan mengalami kerugian sehingga manajer tidak perlu melakukan manipulasi laba untuk menarik perhatian investor. Variabel kontrol market to book value berpengaruh negatif dan tidak signifikan terhadap real earnings management. Arah negatif menunjukkan bahwa semakin tinggi market to book value akan mengurangi tindakan manajer dalam melakukan manipulasi laba. Tingginya harga saham perusahaan memberikan kepercayaan kepada investor dan dapat mengurangi tindakan manajer dalam melakukan manipulasi laba.Namun, hasil ini 
tidak signifikan sehingga tinggi rendahnya market to book value tidak mempengaruhi tindakan manajer dalam melakukan real earnings management. Hal ini disebabkan bahwa manajer akan cenderung melakukan manipulasi laba meskipun harga saham perusahaan di pasar modal tinggi. Tujuan dari manajer melakukan tindakan manajemen laba adalah untuk mendapatkan insentif dari pemegang saham dan menarik investor untuk berinvestasi dalam perusahaan

Berdasarkan hasil tersebut perusahaan sebaiknya dapat meningkatkan kepemilikan saham keluarga agar dapat mengawasi dan mengurangi tindakan manajer dalam melakukan manipulasi laba.Saham perusahaan yang dimiliki oleh keluarga mampu mengkontrol tindakan oportunis manajer dalam usahanya menciptakan laba untuk tujuan pribadi yang terkadang tidak menguntungkan bagi perusahaan. Selain itu, pengelolaan aset perusahaan perlu diperhatikan karena dengan pengelolaan aset yang baik akan meningkatkan laba perusahaan sehingga manajer tidak perlu melakukan tindakan agresif dalam melakukan aktivitas manipulasi laba. Bagi investor yang ingin menanamkan investasi di dalam perusahaan manufaktur dapat memperhatikan struktur pemegang saham perusahaan.Perusahaan yang memiliki struktur kepemilikan keluarga cenderung mampu menghindari tindakan manajemen laba.Selain itu, investor dapat memperhatikan aset yang dimiliki oleh perusahaan.Aset yang besar dan likuid merupakan jaminan bagi investor dalam menanamkan modalnya dan menunjukkan bahwa perusahaan tidak sedang mengalami kebangkrutan. Untuk penelitian selanjutnya disarankan menambahkan variabel lain yang belum terdapat dalam penelitian ini dengan melihat nilai koefisien determinasi yang sangat kecil sebesar $8,7 \%$. Dengan menambah variabel lainnya diharapkan hasil penelitian ini dapat menghasilkan penelitian yang lebih maksimal.

\section{DAFTAR PUSTAKA}

Achleitner, Ann-Kristin, Nina Fichtl dan Christoph kaserer. 2008. Accounting and Real Earnings Management in Family Firms. Center for Entrepreneurial and financial Studies (CEFS). 
Altman, Edward I. 1968. Financial Ratios: Discriminan Analysis and the Prediction of Corporate Bankruptcy. Journal Of Finance Edition 123 September, pp. 589609.

Alves, Sandra. 2012. Ownership Structure and Earnings Management: Evidence from Portugal. Issue 1 Australasian Accounting Business and Finance Journal Volume 6, 2012, 57-74.

Brigham, Eugene F dan Houston. 2006. Fundamental of FinancialManagement: Dasar-Dasar Manajemen Keuangan. Edisi 10. Jakarta: Salemba Empat.

BusheeB. 1998, "The Influence of Institutional Investors on Myopic R\&D Investment Behavior", The Accounting Review, vol. 73 n. 3, pp. 305-333.

Dechow, P. M. Hutton, A. P., Kim, J. H. dan Sloan, R. G. 2012. Detecting Earnings Management: A New Approach.Journal Accounting Research, 50 (2).

Faccio, M., Lang, L., \& Young, L. (2001).Dividends and expropriation.American Economic Review, 91(1),54-78. http://dx.doi.org/10.1257/aer.91.1.54

Ghabdian, Bashir, Navid Attaran dan Omid Froutan. 2012. Ownership Structure and Earnings Management: Evidence From Iran. International Journal of Business and Management, Vol. 7, No. 15, 2012.

Hadani, M. Goraova, M. dan Khan R. 2011. Institutional Investors, Shareholders Activism and Earnings Management. Journal of Business Research, 64 (12), 1352-1360.

Hassanpour, Sara dan Mehdi Nazemi Ardakani. 2017. The Effect of Pre-Bankruptcy Financial Distress on Earnings Management Tools. International Review of Management and Marketing, 2017, 7(3), 213-219.

Hsu, Ming-Feng dan Shiow-Ying Wen. 2015. The Influence of Corporate Governance in Chinese Companies on Discretionary Accruals and Real Earnings Management. Asian Economic and Financial Review, 2015, 5(3): 391-406.

Jensen M. C. dan Meckling, W. H. 1976. Theory of the Firm: Managerial Behavior, Agency Costs and Ownership Structure. Journal of Financial Economics. Vol. 3, Pages 305-360.

LaPorta, R., Lopez-de-Silanes, F., Shleifer, A., \& Vishny, R. (2000).Investor protection and corporate governance.Journal of Financial Economics, 58, 3-27. 
Liu, Jo-Lan dan Ching-Chieh Tsai. 2015. Board Member Characteristics and Ownership Structure Impacts on Real Earnings Management; Evidence from Taiwan. Accounting and Finance Research vol. 4, No. 4, 2015.

Man, C.-K. dan Wong, B. 2013. Corporate governance and earnings management: A survey.Journal of Applied Business Research, 29, 391-418.

Munir, Sa'adiah, Norman Mohd Saleh, Romlah Jaffar dan Puan Yatim. 2013. Family Ownership, Related-Party Transaction and Earnings Quality. AAMJAF Vol. 9, No. 1, 129-153, 2013.

Mohammadi, Farhad dan Peyman Amini. 2016. Investigating The Relationship Between Financial Distress and Earnings Management in Corporations of Accepted in Tehran Stock Exchange. International Academic Journal of Accounting and Financial Management Vol. 3, No. 6, 2016, pp. 41-50.

Nagar, Neerav dan Kaustav Sen. 2016.Earnings Management Strategies During Financial Distress. Indian Institute of Management Ahmedabad India, W.P. No. 2016-02-03 February 2016.

Plat, H.O dan Platt, M.B. 2006. Understanding Diferences Between Finacial Distress and Bankcrupty. Review of Applied Economics.2 (2): 141-157

Roychowdhury, S. 2006. Earnings management through real activities manipulation.Journal of Accounting and Economics, 42(3), 335-370.

Sankar, M. R. dan Subramanyam, K. R. 2001.Reporting Discretion and Private Information Communication Through Earnings. Journal of Accounting Research, 39 (2), 365-386.

Stocken, P. C. dan Verrecchia, R. E. 2004. Financial Reporting Choice and Disclosure Management.The Accounting Review, 79 (4), 1181-1203.

Stockmans, A., Lybaert, N. and Voordeckers, W. (2010) Socioemotional Wealth andEarnings Management in Private Family Firms, Family Business Review, 23(3), pp.280-294.

Swai, Janeth dan Cosmas S. Mbogela. 2016. Accrual-Based Versus Real Earnings Management: The Effect of Ownership Structure: Evidence From East Africa. ACRN Oxford Journal of Finance and Risk Perspectives 5.2 (2016): 121-140. 
Zang, Amy. 2012. Evidence on The Trade-Off Between Real Activities Manipulation and Accrual-Based Earnings Management. The Accounting Review Vol. 87, No. 22012 pp. 675-703. 